SUPPLEMENTARY MATERIAL

Antibacterial activity of commercially available plant-derived essential oils against oral pathogenic bacteria

D.K.R. Bardajía ${ }^{a}$ E.B. Reis ${ }^{\mathrm{a}}$, T.C.T. Medeiros ${ }^{\mathrm{b}}$, R. Lucarini ${ }^{\mathrm{a}}$, A.E.M.

Crotti $^{\mathrm{b}}$, C.H.G. Martins ${ }^{\mathrm{a} * *}$

${ }^{a}$ Laboratório de Pesquisa em Microbiologia Aplicada, Universidade de Franca,

Franca, SP, Brazil; ${ }^{b}$ Departamento de Química, Faculdade de Filosofia, Ciências e

Letras de Ribeirão Preto, Universidade de São Paulo, Ribeirão Preto, SP, Brazil

* Corresponding author.

Av. Dr. Armando Salles de Oliveira, 201 - Parque Universitário

CEP 14404-600 Franca, SP, Brazil

Fone/Fax: (16) 3711-8871

E-mail: carlos.martins@unifran.edu.br 


\section{Antibacterial activity of commercially available plant-derived essential oils against oral pathogenic bacteria}

This work investigated the antibacterial activity of fifteen commercially available plant-derived essential oils (EOs) against a panel of oral pathogens. The broth microdilution method afforded the minimum inhibitory concentrations (MIC) and minimum bactericidal concentrations (MBC) of the assayed EOs. The EO obtained from Cinnamomum zeylanicum (Lauraceae) (CZ-EO) displayed moderate activity against Fusobacterium nucleatum (MIC and $\mathrm{MBC}=125 \mu \mathrm{g} / \mathrm{mL}$ ), Actinomyces naeslundii $(\mathrm{MIC}$ and $\mathrm{MBC}=125$ $\mu \mathrm{g} / \mathrm{mL}$ ), Prevotella nigrescens (MIC and $\mathrm{MBC}=125 \mu \mathrm{g} / \mathrm{mL}$ ), and Streptococcus mutans (MIC $=200 \mu \mathrm{g} / \mathrm{mL} ; \mathrm{MBC}=400 \mu \mathrm{g} / \mathrm{mL}$ ). (Z)-isosafrole (85.3\%) was the main chemical component of this oil. We did not detect cinnamaldehyde, previously described as the major constituent of CZ-EO, in specimens collected in other countries.

Keywords: Cinnamomum zeylanicum; Streptococcus mutans, cariogenic bacteria 


\section{Experimental}

Essential oils and GC-MS analysis

The fifteen essential oils (EOs) tested in this study were obtained by hydrodistillation and donated by the company Body \& Mind Beautiful Aromatherapy (Franca, SP, Brazil). The EOs and their corresponding lot numbers were as follows: Boswellia carteri Birdw. (Burseraceae) (BC, 118); Cedrus atlantica (Endl.) Manetti ex Carrière (Pinaceae) (CA, 101); Citrus x bergamia Risso \& Poit. (Rutaceae) (CB, 114); Citrus limonum Risso (Rutaceae) (CL, 121); Commiphora myrrha (T. Nees) Engl. (Burseraceae) (CM, 140); Citrus paradisi Macfad. (Rutaceae) (CP, 145); Cupressus sempervirens L. (Cupressaceae) (CSe, 126); Citrus sinensis (L.) Osbeck (Rutaceae) (CSi, 100); Cinnamomum zeylanicum Blume (Lauraceae) (CZ, 099); Eucalyptus globulus Labill. (Myrtaceae) (EG, 125); Melaleuca alternifolia Chell (Myrtaceae)(MA, 167); Pinus sylvestris L. (Pinaceae) (PS, 139); Salvia sclarea L. (Lamiaceae) (SS, 197); Thymus vulgaris L. (Lamiaceae) (TV, 137); and Zingiber officinale Roscoe (Zingiberaceae) (ZO, 253).

Gas chromatography (GC-FID) and Gas chromatography-mass spectrometry (GCMS) analysis

The essential oil of Cinnamomum zeylanicum (CZ-EO) was analyzed by gas chromatography (GC) on a Hewlett-Packard G1530A 6890 gas chromatograph fitted with FID and data-handling processor. An HP-5 (Hewlett-Packard, Palo Alto, CA, USA) fused-silica capillary column $(30-\mathrm{m}$ length $\times 0.25-\mathrm{mm}$ i.d.; $0.33-\mu \mathrm{m}$ film thickness) was employed. The operation conditions were as follows: the column temperature was programmed to rise from 60 to $240{ }^{\circ} \mathrm{C}$ at $3{ }^{\circ} \mathrm{C} / \mathrm{min}$ and then held at $240{ }^{\circ} \mathrm{C}$ for $5 \mathrm{~min}$; carrier gas $=\mathrm{H}_{2}$, at a flow rate of $1.0 \mathrm{~mL} / \mathrm{min}$; injection mode; injection volume $=0.1 \mu \mathrm{L}$ (split ratio of 1:10); injector and detector temperatures = 240 and $280{ }^{\circ} \mathrm{C}$, respectively. The components concentrations were obtained by relative peak area normalization (\%). The relative areas were the average of triplicate GC-FID analyses.

GC-MS analyses were carried out on a Shimadzu QP2010 Plus (Shimadzu Corporation, Kyoto, Japan) system equipped with an AOC-20i autosampler under the previously reported conditions (Magalhães et al., 2012). The chemical constituents of 
CZ-EO were identified on the basis of their retention indices on a RTx-5MS relative to a homologous series of $n$-alkanes $\left(\mathrm{C}_{8}-\mathrm{C}_{20}\right)$, using an Rtx-5MS (Restek Co., Bellefonte, PA, USA) fused silica capillary column $(30-\mathrm{m}$ length $\times 0.25$-mm i.d. $\times$ $0.25-\mu \mathrm{m}$ film thickness) under the same operating conditions as well as computer matching with the Wiley 7, NIST 08, and FFNSC 1.2 spectral libraries. The constituents were also determined by comparison of their mass spectra with those reported in the literature (Adams, 1995). Authentic standards available in our laboratory were also co-eluted with CZ-EO to confirm the identity of some EO components.

\section{Bacterial strains and antimicrobial assays}

The minimum inhibitory concentration (MIC) and minimum bactericidal concentration $(\mathrm{MBC})$ of the EOs were calculated by using the broth microdilution method in 96-well microplates. The standard strains from the American Type Culture Collection (ATCC) employed in this study were as follows: Aerobic: Enterococcus faecalis (ATCC 4082), Streptococcus salivarius (ATCC 25975), Streptococcus sobrinus (ATCC 33478), Streptococcus mutans (ATCC 25175), Streptococcus mitis (ATCC 49456), Streptococcus sanguinis (ATCC 10556), and Lactobacillus casei (ATCC 11578). Anaerobic: Porphyromonas gingivalis (ATCC 33277), Prevotella nigrescens (ATCC 33563), Bacteroides fragilis (25285), Fusobacterium nucleatum (25586), Actinomyces naeslundii (ATCC 19039), and Peptostreptococcus anaerobius (ATCC 27337).

The EOs samples were dissolved in dimethyl sulfoxide (DMSO; Synth, São Paulo, Brazil) at $2000 \mu \mathrm{g} / \mathrm{mL}$, followed by dilution in tryptic soy broth (Difco, Detroit, MI, USA) for aerobic bacteria and Schaedler broth (Difco) supplemented with hemin $(5.0 \mu \mathrm{g} / \mathrm{mL})$ and vitamin $\mathrm{K} 1(10.0 \mu \mathrm{g} / \mathrm{mL})$ for anaerobic bacteria. Concentrations ranging from 2000 to $0.976 \mu \mathrm{g} / \mathrm{mL}$ were achieved. The final DMSO concentration was $5 \%(\mathrm{v} / \mathrm{v})$; this solution was used as negative control. According to Clinical and Laboratory Standards Institute (CLSI) guidelines (CLSI, 2009), the inoculum was adjusted for each organism to yield a cell concentration of $5 \times 10^{5}$ colony forming units $(\mathrm{CFU}) / \mathrm{mL}$, for aerobic bacteria, and $10^{6}$ colony forming units $(\mathrm{CFU}) / \mathrm{mL}$ for anaerobic bacteria (CLSI, 2007). One non-inoculated well free of antimicrobial agent was also included to ensure medium sterility. Chlorhexidine dihydrochloride (CHD) (C8527, Sigma-Aldrich, St. Louis, MO, USA) was dissolved 
in tryptic soy broth (Difco) and used as positive control at concentrations ranging from 59.0 to $0.115 \mu \mathrm{g} / \mathrm{mL}$. The microplates (96 wells) containing different concentrations of the EOs and the aerobic microorganisms were sealed with a plastic film and incubated aerobically at $37{ }^{\circ} \mathrm{C}$ for $24 \mathrm{~h}$, whereas the microplates containing the anaerobic microorganisms were sealed with a plastic film and incubated for 48-72 $\mathrm{h}$ in an anaerobic chamber (Don Whitley Scientific, Bradford, UK), in 5\%-10\% $\mathrm{H}_{2}$, $10 \% \mathrm{CO}_{2}, 80 \%-85 \% \mathrm{~N}_{2}$ atmosphere, at $37{ }^{\circ} \mathrm{C}$. After that, $30 \mu \mathrm{L}$ of $0.01 \%$ resazurin in aqueous solution was poured into each microplate reservoir, to indicate microorganism viability. The minimum inhibitory concentration (MIC) values were determined as the lowest concentration of the EO capable of inhibiting microorganism growth. Before the addition of resazurin and in order to determine $\mathrm{MBC}$, an aliquot of the inocolum was aseptically removed from each well and then plated onto Blood agar for aerobic bacteria and Shaedler agar for anaerobic bacteria. The plates were incubated as described previously (Ríos and Recio, 2005). Three replicate assays were accomplished for each microorganism. The sterility controls of TSB and Schaedler broths, culture control (inoculum), chlorhexidine dihydrochloride, and the EOs were performed. The microplates (96 well) were sealed with parafilm and incubated at 37 ${ }^{\circ} \mathrm{C}$, for $24 \mathrm{~h}$.

\section{Acknowledgements}

The authors thank the Brazilian foundations FAPESP (Proc. 2007/54241-8 and 2010/17443-

4) for the financial support, and CNPq for fellowships.

\section{References}

Adams R.P. (1995). Identification of essential oil components by gas chromatography/mass spectrometry. Carol Stream, IL: Allured Publishing Corporation.

Clinical and Laboratory Standars Institute. Methods for antimicrobial susceptibility testing of anaerobic bacteria. 7 ed. CLSI document M11-A7. CLSI, Wayne, Pensilvânia, USA, 2007.

CLSI (2009). Susceptibility testing of aerobic abacteria. Approved standard, $8^{\text {th }} \mathrm{ed}$. CLSI document M7-A8. Wayne, PA: NCCLS.

Magalhães L.G., Souza J.M., Wakabayashi K.A.L., Laurentiz R.S., Vinhólis A.H.C., Rezende K.C.S., Simaro G.V., Bastos J.K., Rodrigues V., Esperandim V.R., Ferreira D.S., Crotti A.E.M., Cunha W.R., Silva M.L.A. (2012). In vitro efficacy of the essential oil of Piper cubeba L. (Piperaceae) against Schistosoma mansoni. Parasitology Research, 110, 1747-1754. 
Ríos JL, Récio MC. (2005). Medicinal plants and antimicrobial activity. J Ethnopharmacol 100, 80-84. 
Table S2. In vitro antibacterial activity (MIC/MBC) of the selected essential oils against anaerobic oral bacteria (in $\mu \mathrm{g} / \mathrm{mL}$ ).

\begin{tabular}{|c|c|c|c|c|c|c|}
\hline $\mathbf{E O}^{\mathrm{a}}$ & $\begin{array}{c}A . \\
\text { naeslundii }\end{array}$ & $\begin{array}{c}B . \\
\text { fragilis }\end{array}$ & $\begin{array}{c}F . \\
\text { nucleatum }\end{array}$ & $\begin{array}{c}P . \\
\text { anaerobius }\end{array}$ & $\begin{array}{c}P . \\
\text { gingivalis }\end{array}$ & $\begin{array}{c}P . \\
\text { nigrescens }\end{array}$ \\
\hline$\overline{\mathrm{BC}}$ & $-1-$ & $-1-$ & $-1-$ & $1000 / 1000$ & $250 / 250$ & $250 / 250$ \\
\hline CA & $-1-$ & $-1-$ & $500 /-$ & $-1-$ & $-1-$ & $-1-$ \\
\hline $\mathrm{CB}$ & $-1-$ & $-1-$ & $-1-$ & $-1-$ & $-1-$ & $500 /-$ \\
\hline CL & $-1-$ & $-1-$ & $-1-$ & $-1-$ & $1000 / 1000$ & $-1-$ \\
\hline $\mathrm{CM}$ & $250 / 250$ & $-1-$ & $250 / 250$ & $1000 /-$ & $250 / 250$ & $1000 /-$ \\
\hline $\mathrm{CP}$ & $-1-$ & $-1-$ & $-1-$ & $-1-$ & $-1-$ & $500 / 500$ \\
\hline $\mathrm{CSe}$ & $-1-$ & $-1-$ & $-1-$ & $-1-$ & $-1-$ & $-1-$ \\
\hline $\mathrm{CSi}$ & $-1-$ & $-1-$ & $-1-$ & $-/-$ & $-1-$ & $250 / 250$ \\
\hline $\mathrm{CZ}$ & $125 / 125$ & $-1-$ & $125 / 125$ & $-1-$ & $250 / 250$ & $125 / 125$ \\
\hline EG & $-1-$ & $-1-$ & $1000 /-$ & $-/-$ & $1000 / 1000$ & $-1-$ \\
\hline MA & $-1-$ & $-1-$ & $-1-$ & $-/-$ & $-1-$ & $250 / 250$ \\
\hline PS & $500 / 500$ & $-1-$ & $1000 /-$ & $-1-$ & $-1-$ & $1000 /-$ \\
\hline SS & $-1-$ & $-1-$ & 2000/- & $-/-$ & $1000 / 1000$ & \\
\hline TV & $1000 / 1000$ & $-1-$ & $500 / 500$ & $-1-$ & $500 / 500$ & $500 / 500$ \\
\hline $\mathrm{ZO}$ & $1500 / 1500$ & $-1-$ & $1000 /-$ & $500 / 500$ & $500 / 500$ & $125 / 125$ \\
\hline CHD & 7.37 & 7.37 & 7.37 & 7.37 & 7.37 & 7.37 \\
\hline
\end{tabular}

${ }^{\mathrm{a}}$ Abbreviations are the same as used in Table 1 . 
Table S3. Chemical composition of the essential oil from Cinnamomum zeylanicum (CZ-EO)..

\begin{tabular}{llll}
\hline Compound & RI & \% RA* & Identification \\
\hline$\alpha$-pinene & 936 & 0.8 & RL MS, Co \\
Camphene & 951 & 0.4 & RL MS \\
$\beta$-pinene & 951 & 0.5 & RL MS, Co \\
Limonene & 931 & 0.2 & RL MS, Co \\
Eucalyptol & 1034 & 0.7 & RL MS, Co \\
Linalool & 1103 & 0.8 & RL MS, Co \\
Camphor & 1149 & 1.0 & RL MS, Co \\
Borneol & 1171 & $\mathrm{t}$ & RL MS, Co \\
Terpinen-4-ol & 1182 & $\mathrm{t}$ & RL MS \\
$\alpha$-Terpineol & 1195 & 0.7 & RL MS \\
(Z)-isosafrole & 1315 & 85.3 & RL MS \\
Cuparene & 1512 & 0.3 & RL MS \\
Spathulenol & 1582 & 0.5 & RL MS \\
Guaiol & 1588 & 0.9 & RL MS \\
NI & 1623 & 1.9 & RL MS \\
Torreyol & 1647 & 1.0 & RL MS \\
$\beta$-bisabolol & 1652 & 0.5 & RL MS, Co \\
Cadalene & 1671 & 3.0 & RL MS \\
NI & 1678 & 0.5 & RL MS \\
Alloaromadendrene oxide II & 1697 & 0.6 & RL MS \\
\hline
\end{tabular}

RI: retention indices relative to $n$-alkanes $\mathrm{C}_{8}-\mathrm{C}_{20}$ on Rtx-5MS capillary column; RA: relative area (peak area relative to the total peak area in the GC-FID chromatogram); RL: comparison of the retention index with the literature; MS: comparison of the mass spectrum with the literature. Co: co-elution with authentic standards available in our laboratory; tr: trace (RA $<0.1 \%)$. NI: not identified; * Average from three replicates. 

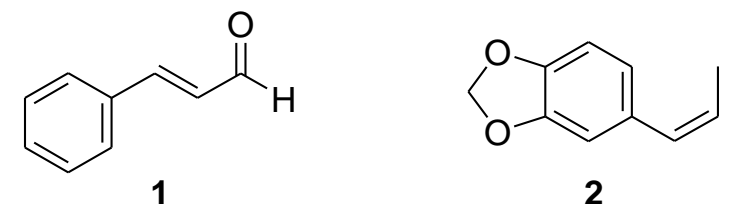

Figure S1. Chemical structures of (E)-cynnamaldehyde (1) and (Z)-isosafrole (2). 